\title{
Scientific Attitude of Young Children through Literature and Project-Based Learning Organization
}

\author{
Veena Prachagool (Corresponding author) \\ Faculty of Education \\ Mahasarakham University, Mahasarakham 44000, Thailand \\ E-mail: veena.p@msu.ac.th
}

Received: September 28, 2021

Accepted: October 23, 2021

Published: November 11, 2021

doi:10.5296/jei.v7i2.19054

URL: https://doi.org/10.5296/jei.v7i2.19054

\begin{abstract}
Young children's scientific attitude is a basic norm of human kind to cultivated actual learning which has been an expected to be a curious, motivated, generous and responsible person. The study aims to investigate scientific attitude of young children through literature-based and project-based learning organization (LPBL). Participants were 25 of young children, age 5-6 years from Mahasarakham University Demonstration School (Elementary), Thailand. The duration of experiment was 8 weeks, 4 days a week and 90 minutes per day that was 32 times. The research instruments were 32 LPBL learning plans, learning behavior observation forms, scientific attitude inventory, and debriefing focuses group interviews. The statistics used in the study were average and standard deviation. The results showed that young children have scientific attitudes was at high level by means of LPBL learning organization. The qualitative data supported that they express scientific attitude accordance with nature of learning.
\end{abstract}

Keywords: Early childhood education, Literature-based, Project-based, Scientific attitude

\section{Introduction}

Scientific attitude is one of the goals of science learning, which is important to cultivate from early childhood. It is a basic norm for promoting science behavior in the pursuit of knowledge in various fields, especially in science (Waddington, 2017; McIntyre, 2019). It can say that scientific attitudes are important to individuals because those with scientific attitudes are rational individuals. It also helps children have a strong mind, always ready to exchange learning with others, and take responsible to society (Halim et al., 2018). Scientific attitude is critical point to start how science should be, developing scientific mind, incubate children to have characteristics in what scientists do. Scientific attitude will be the basis for inviting the desirable good attributes of young children. 
Scientific attitudes are not only necessary for scientists, it is also important for individuals who can be used for their own development (Rutjens et al., 2018). It should be cultivated by early year ages, if young children accept they will result in curiosity to study and grow into a responsible adult. Early childhood education focuses on direct experience, with one of the key principles of science learning being to systematically create (Kos et al., 2021). The meaning of learning process with science experience that are learn meaningfully, happily, and using science process skills. That is, intellectual skills that demonstrate the ability to practice various aspects of thinking processes can be shape children to be scientific mind.

Scientific attitude allows children learn natural surroundings, eager to investigate biological and physical changes. Also, preparing them to face with tomorrow based on responsibility, learning togethers, and learn how learn (Wongchantra \& Nuangchalerm, 2011). Children are like little scientists with suspicion, knowing, having questions about the natural world around them and learning what is around them through experiences all the time. Stimulating and promoting children's learning through scientific processes is therefore a response to the nature of children's learning, a person's habitual skills that help to develop cognition about the world around them.

The development of scientific attitudes in early childhood is achieved through the study of knowledge and use of scientific processes. The quest for scientific knowledge must be a process that is carried out through direct experience with real-world situations, so it can be said that the development of scientific attitudes is important to act in pursuit of knowledge and problem solving. They learn through actions in play and various real experiences (Bonnett et al., 2019). Teachers must let scientific attitude into teaching and learning activity i.e. experiment, playing through group interaction, science storytelling, project assignment, and so on. The lesson must be close to the cognitive development, close to the time, suitable for development, interests and related to prior experiences.

The experience must be in accordance with needs and interests of the child. Scientific attitude development guidelines mentioned above are in line with the process of organizing project-based learning experiences and literature or literature-based and project-based learnings (LPBL). This learning organization aims at enhancing good attitudes towards the pursuit of knowledge. It gives children an experience of places, people and things around them. Literature can engage children interest science and let them to do as imagination through learning in terms of project to gain knowledge (Oppermann et al., 2018; Hansson et al., 2020; van Keulen \& Boendermaker, 2020). Children expand their borders of knowledge and the power of imagination, helping them gain thinking skills. It helps children understand the world and gain new experiences.

LPBL allows children to gain real experience while studying, develops necessary learning skills, starts with the students' interest, love to learn about science, and searching for ways to lead the answer. Based on the above concepts and reasons, early childhood's scientific attitudes play an important role in the success of science learning, effectively solving scientific problems, and are important to the future science interests of early childhood. This research aims to investigate scientific attitude of young children through literature-based and 


\section{Macrothink}

project-based learning organization.

\section{Method}

\subsection{Participants}

The participants in this study is 25 young children, male and female, between the ages 5 yrs. and 6 yrs. who are enrolled in kindergarten year 3, Mahasarakham University Demonstration School (Elementary), semester 2, academic year 2019.

\subsection{Research Instruments}

- Literature-based and project-based learning plan, including the context, learning and key questions of innovation, projects and literature as a base. There are 32 different experience schemes. The duration of the study was 9 weeks and taken for the experiment was 8 weeks, 4 days a week and 90 minutes per day that was 32 times.

- Learning behavior observation in scenarios which is created by researcher.

- Scientific attitude interviewing, children can take responsibility to the interviewing episode, even with obstacles to work, and accept the consequences of their actions, whether they are right or wrong.

- Debriefing focuses group interviews after the scenario takes 10 minutes to interview. A measure of scientific attitudes consistent with desirable conditions from student identification book.

\subsection{Data Collection and Analysis}

The experiment is conducted by organizing LPBL learning experiences of 8 weeks, 4 days a week. It takes 90 minutes a day to measure the scientific attitudes of early childhood after experiments a week. Data were analyzed by mean and standard deviation.

\section{Result and Discussion}

The study revealed that scientific attitudes can be promoted by LPBL. That is, they can question in what they want to know, also express the interest in the results of the experiment. They are eager to seek answers, can offer opinions on the issues, and can act as planned. This may be LPBL allow children to develop scientific skills. Teachers observe children's interests by participating in conversations about things from listening tales or stories that interest them, with each child always having something of special interest in them. Teachers will use this opportunity to draw out their child's hallmarks to motivate them to learn, with the topic they will learn must be based on the needs of most children in the classroom. Scientific attitude of young children can be reported in Table 1 . 
Table 1. Scientific attitude of young children through LPBL learning organization

\begin{tabular}{|c|c|c|c|c|c|}
\hline \multirow{2}{*}{ No. } & \multicolumn{3}{|c|}{ Observer } & \multirow{2}{*}{$\bar{X}$} & \multirow{2}{*}{ Level of scientific attitude } \\
\hline & 1 & 2 & 3 & & \\
\hline 1 & 11 & 10 & 11 & 10.67 & Low \\
\hline 2 & 14 & 15 & 15 & 14.67 & Highest \\
\hline 3 & 15 & 15 & 15 & 15 & Highest \\
\hline 4 & 15 & 14 & 15 & 14.67 & Highest \\
\hline 5 & 12 & 14 & 14 & 13.33 & High \\
\hline 6 & 14 & 13 & 14 & 13.67 & High \\
\hline 7 & 11 & 11 & 12 & 11.33 & Low \\
\hline 8 & 15 & 15 & 14 & 14.67 & Highest \\
\hline 9 & 10 & 10 & 10 & 10 & Low \\
\hline 10 & 14 & 15 & 14 & 14.33 & Highest \\
\hline 11 & 16 & 16 & 16 & 16 & Highest \\
\hline 12 & 14 & 14 & 14 & 14 & High \\
\hline 13 & 13 & 14 & 14 & 13.67 & High \\
\hline 14 & 13 & 12 & 12 & 12.33 & High \\
\hline 15 & 14 & 14 & 14 & 14 & High \\
\hline 16 & 15 & 15 & 15 & 15 & Highest \\
\hline 17 & 12 & 13 & 12 & 12.33 & High \\
\hline 18 & 11 & 10 & 11 & 10.67 & Low \\
\hline 19 & 16 & 16 & 16 & 16 & Highest \\
\hline 20 & 13 & 13 & 12 & 12.67 & High \\
\hline 21 & 11 & 12 & 12 & 11.67 & Low \\
\hline 22 & 14 & 14 & 13 & 13.67 & High \\
\hline 23 & 14 & 14 & 14 & 14 & High \\
\hline 24 & 13 & 13 & 12 & 12.67 & High \\
\hline 25 & 14 & 15 & 14 & 14.33 & Highest \\
\hline $\bar{X}$ & 13.36 & 13.48 & 13.4 & 13.41 & High \\
\hline S.D. & 1.65 & 1.78 & 1.61 & 1.63 & \\
\hline
\end{tabular}




\section{Ml Macrothink}

Learning organization can gain scientific attitude of young children is at high level, consistent with child-centered learning, focusing on children's self-knowledge through a variety of media and learning methods (Stephen \& Edwards, 2017). Teachers provide a learning experience for children to discover their own learning, creating good learning. This research, a topic that early childhood interests, suspects, is the need to learn about stars and space, which is decided by decision-making. The decision making of the vote and the issue of questions that children want to know together, such as "Why does the day not have stars", "Why do we see a full moon, but some days we see a single moon," "Where does a meteor go?" and offers a variety of ways to find answers, such as "go to an expert inquiry about stars".

They have curiosity about natural phenomena and happening surrounding them through method of LPBL learning organization. During the study, simulations and interviewing can keep the empirical data to point out that young children express their eager to understand science behavior (Bridgers et al., 2020). Some groups raised the question "What can I do?" "You're going to have to get it done in time, right?". Planning before an activity, When the researcher interviewed all the children after the activity whether they had planned before they did it, they said, "I don't know if I'm going to do it." All five groups of children responded similarly that they didn't plan at all. However, according to the researcher, all early childhood groups had discussions before they did any activities. It's not just a drawing or a work style.

For example, the words used in early childhood planning, such as "What kind of group are we going to do?", "Simple use a milk carton to make a bridge", "How about making a boat?" In the examples, the statements that convey planning within the group are discussed. They comment on the idea and problem-solving methods together. Although all groups of children say their group didn't plan before doing it, most children can answer that the first step in crafting things. To help rabbits, the situation recounts the process of making scientific attitude.

For example, "Use the bottle cap to make a mattress for the rabbit", "Put the long milk cartons together first and then bring the short milk cartons again". The aspirations of early childhood are also expressed through enthusiasm for the activities of inventing equipment to help rabbits (Figure 1). They expressed interest in the results of the experiment and participating in the chance that their device will help rabbits. When the researcher asked further, how to know if this device would save the rabbit. One early childhood child replied "I can't answer that right now. I have to try it out before it sinks or floats" as shown in Figure 1. However, after the device was tried, some early childhood children found further doubts after another trial. "Why are there so many boats floating around?" "Why do some plexiglass lay on the bridge and roll into the water, some do not fall into the water?". 


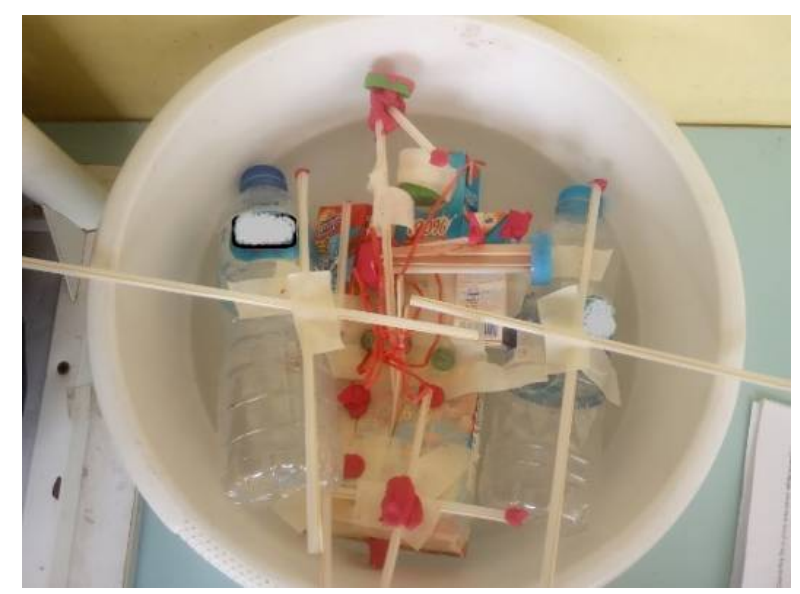

a

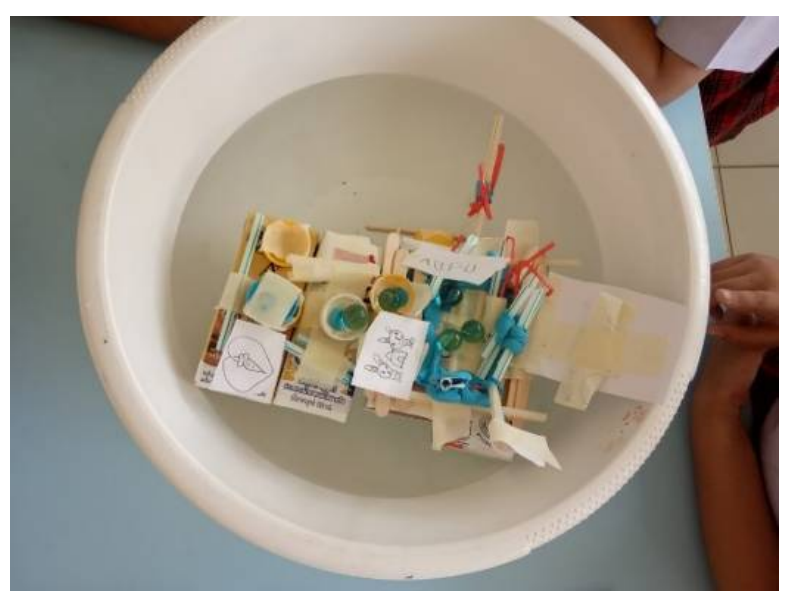

b

Figure 1. Boats that children have invented to help rabbits (a: bottle bridge; b: imaginative bridge)

Responsibility, that is according to the researcher' observations throughout the event, scenarios and interviews with the 5 groups. Four groups of early childhood children who were able to complete the work in time required by each group will be constantly asking for time with the researcher. "How many minutes remaining?". There was one group of early childhood children who were unable to complete the task within the allotted time when the time expired. Researcher noticed an accelerated enthusiasm for inventing more devices. But when the researcher said it was timed and 30 minutes had been completed. The group of early childhood children has not yet put their hands on the device and discussed it in the group "Time's up", "It's not done yet" When the speech ended, the group completed the invention and took 34 minutes. The researcher asked why the work was not completed at the scheduled time, the group's early childhood said. "Because there's so much equipment, it makes it long", "It must be designed to make the boat strong".

The researcher interviewed the early childhooders again during the activity, did anyone not help their friends?. It found that most early childhood children can tell a list of friends who don't help within the group. But he showed no anger that his friend didn't help, only saying that the friend wouldn't help. As for early childhood, a friend who says he doesn't help, he tells his friend why he didn't help. "He's helped a lot, so he's let his friends do it.", and there were two groups of early childhood children who told the researcher that they had helped to do everyone within the group. Most early childhood children of all groups have helped each other invent equipment to help rabbits, but there will be different ways of helping. Some groups talk and express their opinions together, but when they do, they work separately, make different devices and put them together. Some groups have one early childhood child who is separated to invent only one rabbit aid. But when a member of the group put the device together, it follows what the group's friends say.

The researcher concluded that in this joint activity, all groups were helped, but there were 
times when they came to help their friends and isolated them to do activities that were more interested in them than at the time. As part of the recounting of the results, each group of children came together to invent a device to help the rabbit. After the experiment, the researcher asked for more information about the outcome and cause of the float. Most early childhood children can answer why the boat floated, sunk. For example, "Because the milk carton does not have milk in the carton and it can be light and floating" And the last question the researcher used in this interview was to ask the feelings of early childhood after doing rabbit rescue activities. Most early childhood kids say it's a fun activity. I wanted to help the rabbits by inventing something else, but I found that there were two early childhood children who said it wasn't fun because it was hot, and one said they were too sleepy.

Children answered the empirical their scientific attitudes through interviews, experimenting with real things, allowing children to learn from direct experiences suitable for their development, which is consistent with the concept of learning by doing. Learning by action helps children practice things on their own according to their interests, aptitude and potential, learn from practice, enhance necessary skills to self-learning, because they believe that if they do, they will inspire confidence (MacBlain, 2018). Children will have fun continuing to search for knowledge. It also corresponds to activities for children aged 3-6 years old.

Doing hands-on activities is a sense of success, a character of that in the child for the rest of his life. LPBL is a base for children to act on their own thinking and doing as scientists interact with their workplace. Children can learn how to be scientists or enhance skills of learning to be success in adult, they will learn to self-development as well (Elkin et al., 2018). Based on the natural setting, children have the nature of learning with curiosity and eager to learn natural world. Children and scientific attitudes with the lens of LPBL, are interested in knowing, curious and expressing themselves with behaviors. They are including enthusiasm for activities and stories, like experimenting, discussing, questioning, having patience, and behaving science expressions in both positive and negative.

When teachers interact with children frequently in a variety of ways, being interested in what they say or do, giving them the opportunity to explore and experience, encourage them to do things on their own to succeed, will give them all aspects of proper development (Vogt et al., 2018). Teachers should use open-ended questions to organize learning experiences, such as "How can children find answers?" and encourage them to express their opinions or different ways of thinking. Teachers play a role in provoking questions from children. The pursuit of knowledge involves questions that are meaningful to children, but children must be able to find answers by going into observation for themselves and gaining knowledge from sources (El Islami et al., 2018). Developing scientific attitudes that using questions or creating situations encourages students to create good scientific attitudes. Teachers create a relaxing learning environment helps children be ready to learn, develop scientific ideas, imagination, and be able to express their thoughts freely (Nuangchalerm, 2020).

\section{Conclusion}

The instructional practice, LPBL can promote young children in scientific attitude through suitable learning experiences. LPBL allows young children have imagination and learning by 
doing, working with others, and understanding how to responsible in assignment. The results showed that young children have scientific attitudes was at high level by means of LPBL learning organization. However, the study need more study how to create learning environment or learning ecology which promote scientific attitudes.

\section{Acknowledgments}

This research project is financially supported by the Faculty of Education, Mahasarakham University. I would like to thanks Chonlada Arsaiboon for helping in data collection.

\section{References}

Andini, T. E., Hidayat, S., Fadillah, E. N., \& Permana, T. I. (2018). Scientific process skills: Preliminary study towards senior high school student in Palembang. Jurnal Pendidikan Biologi Indonesia, 4(3), 243-250. https://doi.org/10.22219/jpbi.v4i3.6784

Bonnette, R. N., Crowley, K., \& Schunn, C. D. (2019). Falling in love and staying in love with science: ongoing informal science experiences support fascination for all children. International Journal of Science Education, 41(12), 1626-1643. https://doi.org/10.1080/ 09500693.2019.1623431

Bridgers, S., Jara-Ettinger, J., \& Gweon, H. (2020). Young children consider the expected utility of others' learning to decide what to teach. Nature Human Behaviour, 4(2), 144-152. https://doi.org/10.1038/s41562-019-0748-6

El Islami, R. A. Z., Nuangchalerm, P., \& Sjaifuddin, S. (2018). Science process of environmental conservation: Cross national study of Thai and Indonesian pre-service science teachers. Journal for the Education of Gifted Young Scientists, 6(4), 72-80. http://doi.org/ 10.17478/JEGYS.2018.84

Elkin, M., Sullivan, A., \& Bers, M. U. (2018). Books, butterflies, and 'bots: Integrating engineering and robotics into early childhood curricula. In Early Engineering Learning (pp. 225-248). Springer, Singapore.

Halim, L., Abd Rahman, N., Zamri, R., \& Mohtar, L. (2018). The roles of parents in cultivating children's interest towards science learning and careers. Kasetsart Journal of Social Sciences, 39(2), 190-196. https://doi.org/10.1016/j.kjss.2017.05.001

Hansson, L., Leden, L., \& Thulin, S. (2020). Book talks as an approach to nature of science teaching in early childhood education. International Journal of Science Education, 42(12), 2095-2111. https://doi.org/10.1080/09500693.2020.1812011

Juhji, J., \& Nuangchalerm, P. (2020). Interaction between science process skills and scientific attitudes of students towards technological pedagogical content knowledge. Journal for the Education of Gifted Young Scientists, 8(1), 1-16. https://doi.org/10.17478/jegys.600979

Kos, M., Jerman, J., \& Torkar, G. (2021). Preschool children's attitude toward some unpopular animals and formation of a positive attitude toward them through hands-on activities. Journal of Biological Education, 1-18. https://doi.org/10.1080/00219266.2021. 
1877779

MacBlain, S. (2018). Learning theories for early years practice. Sage Publications.

McIntyre, L. (2019). The scientific attitude: Defending science from denial, fraud, and pseudoscience. MIT Press, Cambridge. https://doi.org/10.7551/mitpress/12203.001.0001

Nuangchalerm, P. (2020). TPACK in ASEAN perspectives: Case study on Thai pre-service teacher. International Journal of Evaluation and Research in Education, 9(4), 993-999. https://doi.org/10.11591/ijere.v9i4.20700

Nursa'ban, E., Masykuri, M., \& Yamtinah, S. (2019). Improving student learning outcomes in science subjects through the implementation of PBL-based module. Jurnal Pendidikan Biologi Indonesia, 5(2), 269-276. https://doi.org/10.22219/jpbi.v5i2.7534

Oppermann, E., Brunner, M., Eccles, J. S., \& Anders, Y. (2018). Uncovering young children's motivational beliefs about learning science. Journal of Research in Science Teaching, 55(3), 399-421. https://doi.org/10.1002/tea.21424

Prachagool, V., \& Nuangchalerm, P. (2019). Investigating the nature of science: An empirical report on the teacher development program in Thailand. Jurnal Pendidikan IPA Indonesia, 8(1), 32-38. https://doi.org/10.15294/jpii.v8i1.17275

Prachagool, V., \& Nuangchalerm, P. (2019). Investigating Understanding the Nature of Science. International Journal of Evaluation and Research in Education, 8(4), 719-725. https://doi.org/10.11591/ijere.v8i4.20282

Rutjens, B. T., Heine, S. J., Sutton, R. M., \& van Harreveld, F. (2018). Attitudes towards science. In Advances in experimental social psychology (Vol. 57, pp. 125-165). Academic Press. https://doi.org/10.1016/bs.aesp.2017.08.001

Stephen, C., \& Edwards, S. (2017). Young children playing and learning in a digital age: A cultural and critical perspective. Routledge, London. https://doi.org/10.4324/9781315623092

van Keulen, H., \& Boendermaker, C. (2020). Contributing to Reading Comprehension through Science and Technology Education. Design and Technology Education, 25(2), 117-142.

Vogt, F., Hauser, B., Stebler, R., Rechsteiner, K., \& Urech, C. (2018). Learning through play-pedagogy and learning outcomes in early childhood mathematics. European Early Childhood Education Research Journal, 26(4), 589-603. https://doi.org/10.1080/1350293X. 2018.1487160

Waddington, C. H. (2017). The scientific attitude. Routledge, London. https://doi.org/ $10.4324 / 9781315665382$

Wongchantra, P., \& Nuangchalerm, P. (2011). Effects of environmental ethics infusion instruction on knowledge and ethics of undergraduate students. Research Journal of Environmental Sciences, 5(1), 73-77. https://doi.org/10.3923/rjes.2011.77.81 


\section{Copyright Disclaimer}

Copyright for this article is retained by the author(s), with first publication rights granted to the journal.

This is an open-access article distributed under the terms and conditions of the Creative Commons Attribution license (http://creativecommons.org/licenses/by/3.0/). 